\title{
Research on the Main Problems and Countermeasures of the Security and Stability of Colleges and Universities
}

\author{
Yanmin Song \\ North China Electric Power University \\ Baoding, Hebei, China 071051
}

\begin{abstract}
After entering the new century, the factors that affect the security and stability of colleges and universities are complex and changeable. The problem of political security in Colleges and universities has become more and more prominent, and the pressure of public security and the construction of security and stability work force should be solved urgently. The new task we are facing is that how to correctly analyze the main problems that affect the safety and stability of colleges and universities to take corresponding countermeasures, and make efforts to promote the construction of safe and stable work of the long-term mechanism.
\end{abstract}

Keywords-colleges and universities; security and stability; problem; countermeasure

\section{INTRODUCTION}

The security and stability is an important prerequisite for social stability in china. To ensure the safety and stability of socialist society is the need of socialism with Chinese characteristics development, and it is a necessary condition for the sustainable development of colleges and universities. At present, our country is facing the complex and changeable international environment, the domestic reform has stepped into a crucial stage, the factors that affect the safety and stability of colleges and universities are diversified and complicated. The new task we are facing is that how to correctly analyze the main problems that affect the safety and stability of colleges and universities to take corresponding countermeasures, and make efforts to promote the construction of safe and stable work of the long-term mechanism.

\section{MAIN PROBLEMS FACED BY THE SAFETY AND STABILITY OF COLLEGES AND UNIVERSITIES}

\section{A. Political Security Issue Has Become Increasingly Prominent in Colleges and Universities}

At present, colleges and universities are closely linked with the society in many fields and domestic and international exchanges, resulting in a number of foreign capitalist decadent social trends of thought and domestic social hot issues directly impact on the university. At the same time, China's reform and opening up in the past forty years, has made the world

This article is one of the Party building and ideological and political education research project results of North China Electric Power University, "Construction of Cooperative Mechanism for Campus Security under the Leadership of Party Committees". recognized brilliant achievements, but has also accumulated many contradictions and problems in the market economy and social development. Foreign decadent social trend of thought and social hot issues inter influence, interact and interweave with the reform and opening up over the past 40years in the development of economy and society, having a great influence on the security and stability of colleges and universities.

Moreover, with the deepening of reform, continuous opening of China's higher education and increasing exchange visits of teaching, academic reports, scientific and technological cooperation of foreign colleges and universities, many overseas hostile forces under the cloak of academic exchanges attempt to conceal to colleges and universities in China to penetrate the growing young students, instilling Western values to mislead students to abandon the socialist ideology and accept the western bourgeois ideology; and confounding ethnic and religious problems and misleading the public, in order to destroy the national unity and subvert the purpose of Communist Party. There are some foreign non governmental organizations call the banners of " hoping poor college students to study" and " academic exchange between China and foreign countries", but damage the security of the state and society activities, which are new problems that political security and stability work faces in new period.

\section{B. The Increasing Difficulty of Campus Security Is the Most Important Issue That Affects the Security and Stability of Colleges and Universities}

1) Increasing pressure of campus security. On the one hand, along with expanding the scale of higher education, most colleges and universities show the school running pattern of "a school with several campuses", under the situation of staffing shortage, multi-campus scatters energy of security personnel, which is not conducive to the campus security. The reform of socialization of rear service in colleges and universities makes "the original relatively-closed 'the courtyard' type university campus change into the 'park' type open management state". [1] A large number of social workers who engaged in college logistics service, whose quality are not high, they often do not mind time into the campus, and sometimes invite relatives and friends to play on campus. Some criminals take the opportunity to sneak into the 
campus, stealing, troubling, dong rascal harassment and other illegal and criminal activities, which become the important hidden danger for the campus security and stability. In addition, most of the campus surrounding environment is very complex, not only stores, restaurants and numerous and catering market department store near campus, small traders take roadside stall business impacting on campus and lawbreakers commit crimes in chaos, robbery and theft cases occurring from time to time; other socials mix into the campus to hang, resulting in frequently occurring stealing bicycle events.

On the other hand, the current college students have poor safety awareness, ability of preventing risk and mental health problems. Since the current college students are mostly only child who are cared by parents when they were young, leading to poor self-care ability of children. Under the exam-oriented guidance of the K-12 education only focuses on academic achievement, and today's college students have no systematic received safety education from preschool education until the end of the college entrance examination, lacing of knowledge of their safety, having a poor prevent security ability and lacking of self-protection ability and consciousness. Pampered life environment leads that they develop self thinking personality consciousness, value orientation of practicability and self-behavior. At the same time, because their physical and mental development is not yet in mature period, the complex external environment leads to some psychological barriers of students and the emotions are easily excited and extreme. If there is the slightest mistake to deal with students who have psychological problems, it is easy to cause personal casualty accidents and incidents.

2) Increasing hazards of fire safety. In the large-scale expansion process, due to the restriction of system and funds, colleges and universities generally focus finance, human and material resources on school discipline construction, teaching, scientific research and personnel training as an important indicator of the core competitiveness, and ignore of disregard the transformation of old buildings housing, water, electricity and road network, especially the need for fire protection unable to keep pace with rapid development of colleges and universities. Aging fire facilities and old fire facilities are not updated in a timely manner, so that all equipment overloads operation, fire equipment configuration fails standards and the ability of resisting fire is poor; and now college students' poor fire safety awareness consciousness and dormitory illegal use of high power appliances, resulting in campus fire safety accidents have occurred from time to time.

\section{THE COUNTERMEASURES OF SECURITY AND STABILITY OF UNIVERSITIES}

Security and stability is the most important issue for the sustainable development of colleges and universities, which is not only related to the healthy development of the school, but also related to the physical and mental health and safety of the successors of the socialist cause with Chinese characteristics. It must "seize the main contradiction of the development of things, grasp the inherent laws in the stability of colleges and universities, explore effective measures, transform the focus of work from passive to respond to positive prevention, and establish the safe and stable operation of the long-term mechanism" ${ }^{[2]}$, so that effectively ensure the school's security and stability.

\section{A. Focusing on Building a New Pattern of Safety Education for College Students}

Since the reform, selection assessment of Chinese key universities, 211 Engineering Colleges are mainly as the basis of research level and teaching strength of the school. The focus which school leaders concern naturally is the education and scientific research work, while not to security work which is related to school safety and stability, "stability overrides everything" just "write on a piece of paper, affixed to the wall that is hanged on the mouth". There is a gap for part of the university leaders to understand the importance of safety and stability, so that college students' safety education has not been able to "enter the teaching materials, into the classroom and the implementation of credit". College students' safety education is in charge of counselors in some colleges and universities, which takes the class meeting, engages in talks displays boards and other forms, and content is also more concentrated in the fire protection and traffic safety that are more sporadic. And these often occur after a safety accident, forcing to have to carry out safety education, which is difficult to achieve the desired results with passive non system security education.

To focus on building in university security department (security), supplemented by other departments, coordination between departments, make full use of resources, campus safety education, safety education mechanism of school staff and students oriented. In this mechanism, make full use of the advanced teaching methods and flexible way and make efforts to form a new pattern of safety education for college students, clarify the responsibility of each department in safety publicity and education, strive to achieve the safety education for college students really "into textbooks, into the classroom, implement the credit", strive to build a professional knowledge of safety education of professional teachers and promote the university students' safety education system.

In addition to paying attention to the role of the campus network, the contents of the safety into "network, mail and the phone", making the contents of the safety education into the loved animation, video and other multimedia uploads to the campus network, so that teachers and students can watch and learn at any time, which will greatly improve the timeliness and flexibility of safety education. Also, with mobile phone as necessary communication tools in our daily life, the SMS function has been widely applied for teachers and students in colleges and universities as an information transmission mode in the advanced information age. Editing safety and stable contents, campus hot spots and sensitive issues into phone message sent in a timely manner to the majority of teachers and students to achieve the correct guidance of public opinion, timely eliminate the unstable factors and realize the diversification and practicability. 


\section{B. Strengthening the Building of Safety and Stability in Colleges and Universities}

Strengthening the construction of safe and stable work force in Colleges and universities is an important guarantee to maintain the stability of campus politics and maintain the security of the campus. The security department (safety department) is an important functional departments of colleges and universities, which has the characteristics of all-weather, wide, heavy task, strong policy, high sensitivity and confidentiality, its position is in bitter tired and dangerous in a body. Now most frontline staff of safety guard team in colleges and universities are those who are old, in low education, demobilized soldiers and temporary employment, has a large gap than other management staff in wages, welfare, post allowance, housing and other aspects. According to the security and stability of college team situation, it is urgent to strengthen the security and stability of the team construction, we must reverse the "if there is out of trouble to find the negativity of public security", and should set up the security concept and nip the unstable factors in the bud. Schools should be equipped with high academic qualifications, strong work ability and responsibility cadres for the safe and stable work, selection or hiring a group of about politics, reasonable age structure of record of formal schooling, young people who love the security work to enrich team; paying attention to the training and management of team, increasing operational funds to gradually improve the treatment of workers and improve equipment and their working conditions. Many aspects of the set at the job level, selection and appointment of cadres, labor and welfare adjustment to the security guard work tilt, decided to establish conducive to safe guard the cadres promoted the incentive mechanism, so that form true attention of leaders with various departments and make concerted efforts of our security and stability of colleges and universities.

\section{Building a Long-term Mechanism for Safe and Stable Work}

1) Organizational synergy mechanism: Leading group of school safe and stable work is responsible for the unified leadership of security work, which is in charge of party and government leaders and main principal join in. Safe and stable work is responsible for the disposal of the safety and stability of the whole school, such as timely decision-making, organization and command, and emergency action coordination; each department is responsible for own range of the safe and stable operation, combines with the business sectors, collects and understands the unit safe and stable public opinion information, and timely reports to the team if found any signs of problems; in the event of emergency obeys the command of the safe and stable work, and actively carries out related work. The school security and stability work through "command decision cooperative, collaborative information, and collaborative public opinion coordination mechanism, gradually improve from an emergency to order transition, from a temporary style to tackling the problem of transition, the centralized exercise to the daily pattern of institutional transition, engaged in hold type to prevention beforehand and afterwards asked responsibility type transition, and ultimately the formation of the safe and stable work of the organization and coordination mechanism". [3]

2) Decision making mechanism: The safe and stable work in Colleges and universities must establish a complete, efficient and orderly command and decision-making mechanism, which can respond quickly and deal with the problem in time. School security and stability (emergency) work leading group is college security stable decision-making mechanism, "focus on the relationship between whole and part, between overall situation and key point, from a macro grasp the safe and stable operation of the whole school, active coordination of the various forces, the various departments to communicate and participate in the safe and stable work of the units meet the organic coordination". (4) According to the evolution of the development of the situation, the school security and stability (emergency) work leading group should make the appropriate arrangements at any time to adjust, safely dispose and minimize the loss.

3) Hidden danger investigation mechanism: Hidden investigation mechanism should include the following aspects. One is the time, fixed deposit and demand deposit combined, according to the teaching schedule, do a school wide investigation and security risks at least every semester. In important festivals, meetings and major celebrations, it is necessary to carry out temporary inspection to important sites and links to ensure foolproof. Second is the content, covering fire, utilities, transportation, housing, security, mental health and multiple aspects, through in-depth and meticulous investigation, specifying to the people, even hidden dangers caused by a single screw, and included in the account. Third is that adhere to the "security and stability is as heavy as Mount Tai", "stability is of overriding importance" of consciousness and overcome all difficulties, the courage to tackle the courage in the rectification, resolutely rectificate in place, which the projects included in the account of rectification with a highly responsible attitude for the staff and students and social to ensure the stability of the school.

4) Emergency handling mechanism: There is an old saying "Preparedness ensures success, unpreparedness spells failure." "A man without distant care must have near sorrow." Colleges and universities must constantly improve the emergency response mechanism to deal with various complex situations, in order to effectively prevent and control the work in time. Emergency disposal mechanism should adapt to the "two sessions", "emergency", "sensitive anniversaries of the event", holidays and other special needs to set up a clear responsibility of the organization and leadership, establish a leadership coordination, professional and technical, propaganda and ideological and political and other departments involved in the elite teams, combining with the actual conditions of the school to simulate and expect events that likely to occur under a variety of circumstances and conditions and corresponding disposal measures, so as to in case of emergency do a good job work to deal with emergencies and effectively concentrate force within the 
fastest speed. Practice has proved that these plans in the disposal of emergencies can win the initiative and opportunity for us to play a good role for school and social security and stability.

\section{CONCLUSION}

All in all, we need to further raise awareness and make security and stability as a precondition for the development of the school. By constructing a long-term mechanism for the security and stability of colleges and universities, to improve the security and stability of university organization and team, to amplify the safety management system and mechanism and to earnestly do a good job security and stability of colleges and universities.

\section{REFERENCES}

[1] Song Yanmin, Li He, On the Reform of the Security Work in Colleges and Universities under the New Situation, Journal of Weifang industry Career Technical College, NO.3.2014.

[2] Dong Huaming, Analysis on the Factors Affecting the Safety and Stability of Colleges and Universities at Present, Chinese Adult Education, NO.17.2011.

[3] Zhang Yan, Miu Jinxiang, Constructing the Coordination Mechanism of the Stable Work in Colleges and Universities, School Party Building and Ideological Education (in the first half), NO.9.2008.

[4] Li He, Song Yanmin, Building a Long-term Mechanism for Safe and Stable Work, Gansu Social Sciences, NO.3.2014 